\title{
Moral dilemmas of the Brazilian public management in the face of the COVID-19 pandemic
}

\author{
Laís Silveira Santos 1
}

1 Universidade Federal de Santa Catarina, Florianópolis / SC - Brazil

Due to the pandemic of the new coronavirus, Brazilian public management has made decisions of public interest that directly impact the lives of practically all Brazilians and present several intrinsic ethical issues. From this context, this article aims to identify and discuss some of the main moral dilemmas that challenge Brazilian public management in the face of the pandemic. To this end, news reports were selected from journalistic websites that presented dilemmas that occurred or are still occurring in Brazil. Six thematic areas were identified: social distancing; use of big data in the pandemic's management; the performance of health professionals; federal emergency aid and bureaucracy; school closures and online learning; and release of prisoners as a preventive measure. It was observed that, in contexts of crisis, citizens and public managers are displaced from their status quo, which leads to new forms of moral reasoning. These issues demand continuous reflection and debate on the ethical aspects of the pandemic, especially to the governments' social and moral obligations and the limits of such disruption to citizen's rights in a period of crisis.

Keywords: COVID-19; moral dilemma; public management.

\section{Dilemas morais que circundam a gestão pública brasileira no enfrentamento da pandemia do novo coronavírus}

Devido à pandemia do novo coronavírus, a gestão pública brasileira tem tomado decisões de interesse público que impactam diretamente a vida de praticamente todos os brasileiros e apresentam diversas questões éticas intrínsecas. Diante deste contexto, este short paper tem como objetivo identificar e debater alguns dos principais dilemas morais que desafiam a gestão pública brasileira no enfrentamento da pandemia. Para tanto, foram selecionadas notícias de websites jornalísticos que apresentassem situações éticas que ocorreram ou ainda estão ocorrendo no Brasil. Seis áreas temáticas com dilemas foram identificadas: distanciamento social; uso de big data no gerenciamento da pandemia; atuação dos profissionais de saúde; auxílio emergencial federal e burocracia; suspensão de aulas e atividades educacionais presenciais; e liberação de presidiários como medida de prevenção. Percebeu-se que, em contextos de crise, cidadãos e gestores públicos são afastados de seu status quo, o que leva a que novas formas de raciocínio moral sejam desenvolvidas. Essas questões demandam uma contínua reflexão e debate sobre os aspectos éticos da pandemia, principalmente em relação às obrigações sociais e morais dos governos e aos limites dessa interferência no direito individual dos cidadãos em um período de crise.

Palavras-chave: COVID-19; dilema moral; gestão pública.

\section{Dilemas morales de la gestión pública brasileña en el afrontamiento de la pandemia del nuevo coronavirus}

Debido a la pandemia del nuevo coronavirus, la administración pública brasileña ha tomado decisiones de interés público que afectan directamente la vida de prácticamente todos los brasileños y presentan varios problemas éticos intrínsecos. Ante este contexto, este breve documento tiene como objetivo identificar y discutir algunos de los principales dilemas morales que desafían a la administración pública brasileña en el afrontamiento de la pandemia. Para ello, se seleccionaron noticias de sitios web periodísticos que presentaban situaciones éticas que ocurrieron o aún ocurren en Brasil. Se identificaron seis áreas temáticas con dilemas: distanciamiento social; uso de big data en el manejo de la pandemia; desempeño de los profesionales de salud; ayuda federal de emergencia y burocracia; suspensión de clases y actividades educativas presenciales; y la liberación de prisioneros como medida preventiva. Se observó que, en contextos de crisis, los ciudadanos y los administradores públicos son sacados de su status quo, lo que hace que se desarrollen nuevas formas de razonamiento moral. Estas cuestiones exigen una reflexión y un debate continuos sobre los aspectos éticos de la pandemia, especialmente en relación con las obligaciones sociales y morales de los gobiernos y los límites de las interferencias en el derecho individual de los ciudadanos en un período de crisis. Palabras clave: COVID-19; dilema moral; gestión pública.

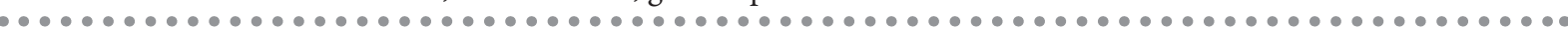
DOI: http://dx.doi.org/10.1590/0034-761220200219x

Article received on April 27, 2020 and accepted on May 26, 2020.

ISSN: 1982-3134@() (1)

[Translated version] Note: All quotes in English translated by this article's translator. 


\section{INTRODUCTION}

In January 2020, the World Health Organization (WHO) began discussions on the formation of a public health emergency of international concern (PHEIC) due to the appearance of a new coronavirus in China in December 2019. On March 11, 2020, COVID-19, a disease caused by the virus, was declared a "pandemic" by the WHO. An epidemic of infectious disease had been recognized. In Brazil, the first case of COVID-19 was registered on February 26, 2020. In June of the same year, the country had confirmed 600,000 cases and more than 33,000 deaths, in addition to asymptomatic and unreported cases (Ministério da Saúde do Brasil, 2020).

As the pandemic is a situation of public interest and general responsibility, the structures linked to Public Administration are placed at the head of its management, although other segments are also involved, such as market, religious, scientific, and civil society institutions. There is also the fundamental role of citizens who, as possible victims, are charged with their civic and moral responsibility to take preventative measures to help control the disease.

Within this context of collective and individual actions, ethical tensions emerge as conflicts, motivated by a) different values and objectives (Aung, Rahman, Nurumal, \& Ahayalimudin, 2017), b) limited and scattered information, c) multiple demands, and d) scarcity of resources (Santos \& Serafim, 2020). These tensions lead to moral dilemmas that are more evident, making the ethical decision more complex. According to Santos (2019), the ethical decision is the one that can benefit or harm other people. The tensions can also influence public policies and government actions in the management of the pandemic.

This short paper contributes to the debate on the response to the crisis of the new coronavirus by identifying and discussing some of the main moral dilemmas that challenge Brazilian public management in facing the pandemic. The ethical debate in public management does not necessarily provide a path to follow, but it allows clearer and morally justified reasoning in times of crisis.

\section{MORAL DILEMMAS AND ETHICAL DECISIONS}

Santos (2019, p. 52, our translation) defined moral dilemma as "[...] experiencing a tension between the possible paths of moral action in the search for the best decision in a given circumstance, and the circumstance is assessed from the perspective of the one who interacts with the moral dilemma." A moral dilemma is characterized by: "(a) being a complex situation, (b) created by the conflict of multiple obligations and/or interests - considered correct - that could be exercised in isolation, (c) however, in a given context, only one course of action can be chosen [...]" (p. 52, our translation). Dubnick and Justice (2006) consider that the real dilemma for those who occupy functions in public administration is the choice between what is believed to be ethically mandatory "here and now" and the possibility that the same decision can be condemned in another context.

According to Waldo (2000), every decision that aims at the public interest is inevitably complex - morally speaking - regardless of its context. For Cooper (1998, p. 90), “[...] confronting conflicting responsibilities is the most typical way public administrators experience ethical dilemmas." Among the most common conflicts are the 'conflict among interests', 'conflicts among various sources of authority,' and 'conflict of responsibilities.' 
In order to assist in the analysis of ethical issues, making tensions more visible for decisionmaking, Kidder (2007) developed four paradigms for classifying right-vs.-right dilemmas: 'justice' vs. 'compassion,' 'short' vs. 'long term,' 'individual' vs. 'community', and 'truth' vs. 'loyalty.' According to the author, "[...] these four paradigms help us to describe the basic issues at the heart of so many ethical conflicts" (Kidder, 2007, p. 150, our translation).

Santos (2019) differentiates the moral dilemma into horizontal and vertical. Horizontal dilemmas have an unclear ethical hierarchy of priorities, i.e., they do not present a clear path to follow. They are dilemmas that rationalist philosophers call 'insoluble,' even though they require a solution from decision-makers when they occur. Vertical dilemmas present an evident ethical hierarchy due to legal circumstances and moral autonomy to make the decision.

As an example of a moral dilemma in a crisis context, French and Raymond (2009) report that, in 2002, health officials from 46 different states in the US came together to determine which factors were most important in the case of a flu pandemic. The officials were considering the factors 'reducing death,' 'reducing disease,' 'limiting impact', 'ensuring essential services,' or 'implementing equitable distribution of a vaccine.' Participants could not reach a consensus, but they had to decide how to equitably balance the treatment of the infected, and about measures such as civil confinement and the need to maintain essential services as the work of health professionals.

This example resembles the reality in the face of the COVID-19 pandemic, except for the substantial difference that, at the time of writing (June 2020), there is no vaccine against COVID-19, nor an effective treatment. This condition makes decisions much more complex and challenging, reinforcing the need for reflection and debate on the ethical issues faced during this crisis. Santos (2019, p. 288, our translation) argues that " $[. .$.$] the recognition and understanding of moral dilemmas can provide timely clues for the$ development of best management practices for public organizations, helping in the analysis of moral issues considering different perspectives and paths of action." Thus, the expectation is that such reflection will lead to a better and safer process of democratic and citizen-oriented public management.

\section{METHODOLOGY}

This study uses a qualitative approach to reach the core of the moral dilemmas within the Brazilian public management, addressing the concrete challenges imposed by the COVID-19 pandemic and the complexity around the issue of the moral dilemma. Data was collected through documentary research, based on texts published, in Portuguese, on journalistic websites that presented dilemmas that had already occurred or are occurring in the face of the pandemic in Brazil. These texts bring a variety of information and contribute to building the history of the moral dilemma plots selected for analysis. Thus, the time dimension of the facts is perceived, as well as the individuals, groups, behaviors, mentalities, and practices present in the situations reported (Cellard, 2008).

The topics that guided the search for cases in the Brazilian public management analyzed in this study were selected based on the suggestions found in the literature on ethics and emergency management to identify moral dilemmas (Aung et al., 2017; Geale, 2012; Santos \& Serafim, 2020). The topics were 'triage,' 'relief funds,' 'risk communication,' 'professional support,' 'resource allocation,' 'linguistic, religious, and cultural differences,' 'vulnerable groups,' 'surveillance of communicable diseases', and 'lockdown/social distancing.' 
After selecting the topics, the researchers collected news related to them within the context of the pandemic and the Brazilian public management. Data collection was carried out between April 20 and 26, 2020 through an electronic search portal with the words (in Portuguese): 'pandemia' (pandemic), 'coronavírus,' 'Brasil', and words that refer to the public administration, such as 'governo'(government), 'serviço público'(public service), 'saúde pública' (public health), 'Estado' (state), 'gestão pública' (public management), and 'administração pública' (public administration). The results obtained from the search were analyzed according to their fit to the concept of moral dilemma and its fundamental characteristics: a complex situation, created by the conflict of multiple obligations that could be exercised alone, but, due to the context of pandemic management, only one course of action can be adopted (Santos, 2019).

To avoid only one description of events, the study sought cases of moral dilemmas in more than one journalistic website. Therefore, the sources of information, recommendations, and clarifications were expanded to elucidate the dilemmas under debate (Figueiredo, 2007).

\section{MORAL DILEMMAS EXPERIENCED IN BRAZIL'S RESPONSE TO THE COVID-19 PANDEMIC}

The situations identified as moral dilemmas in Brazil's response to the COVID-19 pandemic are described in this section, together with their ethical perspective. Six thematic areas were identified: social distancing, use of big data in the pandemic's management, the performance of health professionals, federal emergency aid and bureaucracy, school closures and online learning, and release of prisoners as a preventive measure.

\subsection{Social distancing as a preventive measure: necessity, restriction of rights, and civic/moral responsibility}

As one of the measures to prevent the spread of the new coronavirus, the WHO recommends social distancing to those who can stay at home, that is, anyone who is not considered an essential worker. The state of Santa Catarina was the first in Brazil to decree lockdown, on March 18. Commerce, gyms, temples and churches, public transportation, parks, and public spaces were closed. Measures like these were adopted, with more or less flexibility, throughout the country's states and municipalities.

On March 25, the newspaper O Estado de S. Paulo identified some type of restriction in at least 22 Brazilian states. These were not only 'sanitary barriers,' but restrictions that affected - or still affect the citizens' right of freedom of movement (Gazeta do Povo, 2020), such as in the city of Porto Alegre, where the mayor issued a decree restricting the movement of people over 60 years of age, with a fine for non-compliance (GaúchaZH, 2020).

\section{Ethical Perspective}

The decision of whether to adopt social distancing or lockdown has numerous consequences for a large portion of the population. When addressing these issues and considering the unforeseeable consequences of such measures, public managers and citizens face short-term versus long-term moral dilemmas, and risks versus benefits regarding future perspectives (Kidder, 2007).

Discussions on social distancing are focused on the restriction of citizens' rights to freely move versus the citizen's contribution to public health in times of crisis. Public management faces the 
challenge of reconciling individual freedom with the task of reducing the spread of the virus. Rego et al. (2020b, p. 4, our translation) argue that "[...] social distancing can and should be voluntary, except in cases of people already known to be contaminated, due to the possibility of harming others and thereby injuring the ethics of reciprocal respect." This ethical perspective could also be called 'ethics of care' or 'ethics of virtues'. According to this moral philosophy, the individual has to show the intention of being a good person and caring for others involved in the situation, being empathic (Kidder, 2007).

From an individual point of view, social distancing can be seen as an act of solidarity, because, in this case, the consequences of the acts affect the whole society. Individuals taking care of themselves are also taking care of others. Thus, by recommending that people stay at home as much as possible, WHO and public officials who agree with this measure are sharing a practice of mutual respect, transferring to the population the moral responsibility related to stopping the spread of the new coronavirus.

However, even with equal values, people have different needs. So, how do those who need to work daily to survive, or those who do not have water, electricity, and other conditions to engage in lockdown properly manage to be confined 24 hours a day at home? In the case of the socially vulnerable population, imposed social distancing measures may be disregarding the specific context of each reality. The measure, therefore, becomes discriminatory, unequal, and demonstrates a utilitarian perspective that places the end of the action above the individual's wellbeing.

\subsection{Big Data in pandemic management: 'big brother' or a management tool}

The tracking of mobile phones is a tool to reduce the spread of the new coronavirus. Through monitoring the devices, authorities can take action in real-time to disperse people and advise them on the risks of COVID-19. Experts argue that, in the current format, governments cannot access people's identity and telephone number (Magenta, 2020). However, some people fear that this monitoring practice may limit privacy and freedom of movement, which are guaranteed in Brazilian legislation (Barone \& Desideri, 2020).

\section{Ethical perspective}

The ethical debate about the use of personal data as a technological tool for surveillance and reduction of agglomerations is similar to that carried out on measures of social distancing: how far can collective interest measures advance or influence individual interest? For public management, in times of crisis, this dilemma classifies itself as a vertical one (Santos, 2019) since personal convictions are minimized by a sense of responsibility for controlling the pandemic. Therefore, decision-making is facilitated due to emergency circumstances and priorities in the ethical decision hierarchy.

From a utilitarian point of view, the right to individual privacy can be minimized because of a more significant good to a higher number of people in a public health crisis. However, this measure - when not authorized by the individuals - can be seen as a risk of establishing a state of permanent surveillance over individual freedom and, perhaps, of opening a path for other actions to curtail citizen's autonomy.

In the case of the adoption of such surveillance due to the pandemic, it is important to consider the temporal dimension of this ethical issue, since the legal aspect has already been overcome. 
According to Drozenová (2016), in the field of ethics in times of crisis, some moral values may have priority. For the author, this issue is not a case of moral relativism, but a necessity imposed on public managers by the pandemic.

The deontological philosophy, however, disregards this temporal and circumstantial dimension (Drozenová, 2016). For those who defend this moral perspective and those who are against the unauthorized use of personal data, even with the justification of the pandemic, the action's outcome - using the data to monitor agglomerations and prevent new infections, for instance - is not ethically justified. In this case, foreseen consequences are not strong enough arguments to justify this as a 'good measure' (Treviño \& Nelson, 2010).

\subsection{Health professionals: honor the profession, protect your family and yourself}

Health teams face dilemmas during the pandemic. In the fight against the new coronavirus, professionals from all over the world have been infected, some dying even with the use of protective equipment - which is already scarce in several countries (BBC, 2020). While they are considered essential workers, many of them are also within the risk group for the disease, as is the case with the doctor R. B., who has worked for 51 years in a public hospital in São Paulo. When in social distancing, due to being part of the risk group, the doctor mentioned in an interview to a journalist: "it is a difficult situation. There are 30 colleagues in my team, I am the oldest, but many are over 60 . If I decided to be working at this point in my life, I should be there instead" (Rossi, 2020).

These professionals are not only concerned about autoinfection. They also fear to be a vector for the virus, since they are likely to be infected at work and consequently more likely to contaminate someone else or take the virus back to their own home (Carbone, 2020).

\section{Ethical perspective}

Zack (2009) argues that, even in crises, frontline professionals - such as health workers, police officers, firefighters, urban cleaning - should be seen as regular people, with fears, uncertainties, and challenges, instead of 'fictional superheroes.' They also have a family, a home, worries, and can be or are - personally affected, while dedicating to the control of a matter of public interest, such as the pandemic. In this context, moral dilemmas of different types can arise, such as conflicts between the professional 'roles' vs. 'personal life,' 'justice' vs. 'compassion,' and professional choices in the face of scarce resources, such as: which life to prioritize?

Each dilemma will usually be intense and painful (Kidder, 2007), due to the different commitments and expectations present in the work of these professionals during a crisis such as the COVID-19 pandemic. However, McEntire (2015) argues that frontline professionals recognize the dangers and conflicts inherent in their work but develop their activities regardless. These professionals rarely stop working to focus on their personal needs. Furthermore, professional norms do not always need to correspond to the professional's values and norms and vice versa (Aung et al., 2017), as is the case of those who are part of the risk group, but feel it is their moral duty to act alongside their teammates. 
Finally, it is possible to observe the emergence of reports of escalating moral dilemmas in the professional activity of public health workers, such as having to choose which life to prioritize when there is no equipment or resources to treat the population. Cities like Manaus, Fortaleza, and São Paulo have faced this situation with people who have COVID-19 symptoms or have been diagnosed with the disease. It should be noted that, in the case of Brazilian public health, limited resources were already part of the reality of numerous cities, intensifying or gaining greater visibility with the pandemic.

The triage carried out in times of crisis, and the difficult medical choices indicate that the dilemma can be characterized as genuine and horizontal, that is, with options that are part of the same moral system - preserving lives -, whose ethical hierarchy of priorities is sometimes unclear or questionable (Santos, 2019).

\subsection{Emergency aid: necessity, bureaucratization, and risk of misconduct}

The federal government provided emergency aid of $\mathrm{R} \$ 600.00$ to part of the population as a measure to reduce the economic impacts caused by the pandemic. The benefit is intended for informal, selfemployed workers, individual micro-entrepreneurs, and the unemployed. Among the requirements for receiving the benefit, the citizen has to resolve any issues regarding the Individual Taxpayer Registration (CPF) and the citizen's registration on a digital platform.

Pending issues related to the CPF may be resolved online and free of charge through the website of the Federal Revenue of Brazil (RFB). However, in cases where it is not possible via the Internet, the service occurs in person at one of the RFB units. Financial assistance for those who are unable to work (because of a lockdown, for example), ended up leading to lines and agglomerations at the state-owned bank responsible for the payments (Caixa Econômica Federal - CEF) and RFB units in different Brazilian states (Receita Federal, 2020).

Since April 13, thousands of people - including pregnant women and the elderly - have spent hours on the sidewalks, sometimes all night in line, to be attended. In an attempt to remedy this agglomeration, one of the Federal Regional Courts suspended the requirement to resolve pending issues with the CPF. However, the government appealed the decision to avoid fraud and deviations in the system, thus maintaining the requirement (Dondossola, 2020).

\section{Ethical perspective}

The law must be respected unless this is impossible. It is crucial to be flexible when humanity must prevail. (Freitag, 2005, p. 87, our translation)

Fortes et al. (2020) mention that the right to income must be interpreted not as a privilege, but as an unconditional commitment by the whole society to the subsistence of its members. Therefore, it is crucial to create solutions to respond to the needs of the most vulnerable population. Solutions, in this case, should consider the use of technology. Villoria (2011) believes that the search for efficiency 'at all costs' can generate tensions that involve elements of legality and objectivity, which are also essential in public management. 
In the case examined, the policy-makers anticipated fraud and misconduct in the process of disbursing financial aid. Thus, the bureaucracy was used as an instrument of an ethical nature (Santos, 2019) to “[...] preserve public goods" (Cordeiro, 2017, p. 864, our translation). This measure generates a conflict of roles in public administration, where the social aspect collides with the need for control.

When writing about disbursing financial resources and the dependency on bureaucracy, Peci (2020) highlights: "Each day of delay in transferring the money to the legitimate recipients will result in hunger and unsatisfied basic needs, companies' bankruptcy, unemployment, and lost lives." Faced with this dilemma, it is valid to question for whom or what the state apparatus and public actions are for.

\subsection{School closures and online learning}

To avoid agglomerations and displacements, in mid-March, public and private schools were closed throughout the country. To deal with the situation, some educational institutions have adopted online learning. However, not all students in the country have access to computers and the Internet, to allow them to continue their studies satisfactorily. According to a survey conducted in 2018 by the Internet Steering Committee in Brazil (CGI.br), 58\% of Brazilian households do not have access to computers, and 33\% do not have access to the Internet, with access being more restricted in the lower classes (Valadares, 2020 ).

Seeking alternatives for the fulfillment of the school year, on April 20, the City Council of Florianópolis approved a bill authorizing the special regime of non-classroom learning activities for basic municipal education. According to the Municipal Secretary of Education, children who do not have access to the Internet receive printed materials delivered by schools $(G 1,2020)$. Similar decisions have been taken or considered in municipal, state, and federal schools and universities in Brazil to avoid the academic year or semester not being completed, dropping out of school, reducing academic performance, among other impacts.

Even with the school closures and uncertainty about the return of lessons in person or online, legal requirements, commitments, and specific events are maintained, such as the example of the National High School Exam (ENEM). The federal government proposed to carry out the exam on the same date scheduled before the pandemic was declared (Saldaña, 2020). However, after several contrary manifestations and filing a public civil action by the Public Defender's Office (DPU), the Ministry of Education decided to postpone the exam (Lesme, 2020). There is also the situation of private institutions that may have their contracts interrupted and school fees unpaid in case of non-compliance with educational activities, leading to possible redundancies and financial losses.

\section{Ethical perspective}

The moral dilemmas in the face of the suspension of face-to-face classes throughout Brazil and the adoption of other teaching strategies are based on legal, educational, and social issues. How to continue guaranteeing the right to learning - and quality - without considering the situation of educational 
and social inequality in the country? Furthermore, it is not reasonable to disregard the problems resulting from interrupting educational activities while social distancing

Although the law providing guidelines for education in the country (LDB) states that the school calendar must adapt to circumstances, the difficulties faced are many: families that do not have guidance or technology for home education, financial impacts, operational adjustments, and labor issues. The National Education Council (CNE) has presented these challenges as justification for the adoption of non-classroom activities in order to carry out educational activities that would allow students to complete the current academic year still in 2020 (CNE, 2020).

Such initiatives have an instrumental ethical logic of maximizing resources and productivity that may disregard important losses in the teaching-learning process, such as the students' learning through living with peers and the school community, the instruction based on the intervention of teachers (who are technically prepared professionals), the complexity of educational work. In this way, a short-term vs. long-term moral dilemma is inflicted (Kidder, 2007). The situation suggests that any of the paths adopted will have an impact on students and educational institutions, whether now (maintaining the educational system), or in the future (in the quality of the education).

A dilemma of 'us vs. them' can also be observed when discussing the issue of education. Private institutions started experiences of remote teaching before public institutions. In addition, a significant portion of students in public institutions does not have a computer or Internet access. In contrast, other colleagues do and will be able to continue their studies, even when 'the finish line' is the same - in Brazil, all students seeking higher education must compete for places in universities based on their performance in the ENEM exam.

From this ethical point of view, Zack (2009) states that, in crises, utilitarian ethics is most frequently applied, following the principle of public administration efficiency. According to this moral philosophy, the criterion for action is one that reaches the largest number of people, considering the limitation of resources or the possibility of serving everyone.

\subsection{Release of prisoners as a measure to contain the pandemic}

The Brazilian prison system has approximately 752 thousand detainees, in addition to 83 thousand employees (Adler, 2020). As one of the government measures to contain the pandemic in this environment, the National Council of Justice (CNJ) published Recommendation 62/2020 concerning the release of inmates whose provisional freedom has been conditioned on the payment of bail and the transfer of detainees to other regimes - such as their home. The recommendation prioritize pregnant women, nursing mothers, the elderly, and provisional prisoners who have been incarcerated for more than 90 days (Conselho Nacional de Justiça [CNJ], 2020).

The justification for this recommendation is based on the precarious situation of the prison system, with serious risks of the spread of the coronavirus. Given this recommendation, judges had the difficult decision to keep people in prison (assuming the risk of spreading the virus) or to release a significant part of the prisoners (against the dominant punitive system) (Mello, 2020).

When pronouncing on the situation, the former Minister of Justice and Public Security, Sergio Moro, defended that " [...] we cannot, under the excuse of protecting the prison population, excessively make vulnerable the population that is outside the prisons" (David, 2020, s.p.). 


\section{Ethical perspective}

In this type of moral dilemma, inmates can be seen as a vulnerable public, considering the challenges to prevent contamination of the new coronavirus in Brazilian prisons. This situation becomes an ethical issue since they do not have equal conditions of access to sanitation resources (even though part of the Brazilian population suffers the same restriction in their neighborhoods) in comparison to free citizens.

There is also a moral conflict of authority and objective responsibilities (Cooper, 1998) against the recommendation of the CNJ. Both issues, 'health' vs. 'justice,' have decent legal and moral arguments. In the same way, the consequences of both paths of action are shared with society. By releasing inmates, the prison community and the public health system benefit from preventing the emergence of new cases of the disease. At the same time, society becomes more exposed to crime and violence. Furthermore, considering this scenario, the ethical decision was not only 'whether to release' some prisoners but to know the limits of that release, and when to stop granting such benefit (Burke, 2001).

\section{CONCLUSION}

Based on the news about the pandemic in Brazil, this short paper identified and discussed some of the main moral dilemmas faced by the Brazilian public management in the actions to prevent and combat COVID-19. The comments presented here do not refer to a legalistic analysis of crisis management, but to a debate with possible ethical views on the issue, through different moral theories. In this sense, the study shares the view by Rego et al. (2020a, p. 1, our translation) when they state that the "[...] moral implications [of the pandemic] in the context of the Brazilian reality is, for us, an invitation for reflection."

It was possible to observe that, in the context of crisis, citizens and public managers are displaced from their status quo. This situation leads to the development of new forms of perception and moral reasoning for existing and new public problems. Therefore, reflections on the ethical aspects of the pandemic continue to be necessary, highlighting the social obligations of governments toward citizens and essential workers, as well as the disruption to individuals' autonomy and freedom.

It should be noted that the study did not have the objective of exhausting existing moral dilemmas, since they are diverse and will continue to arise. The intention was to discuss some of the most common and complex at the present moment. However, an important ethical issue was not included: the presentation of 'economy' vs. 'health' as a moral dilemma in the pandemic. In this case, it is necessary to make some considerations.

Since the crisis also affects the economy, leaders are suggesting, from a morally utilitarian perspective, that some people must die so that many others can live (Gak, 2020), thus avoiding an economic crisis. However, based on the following assumptions, this is a false moral dilemma for the public administration: (1) life is a fundamental principle and constitutionally protected right, (2) the economy only exists because there is life and a space of common interest (Lisbon, 2018), and (3) Public Administration has a moral obligation to create mechanisms for citizens to be healthy, safe, and have integrity. Public leaders are morally responsible for making legitimate decisions to prevent citizens from finding themselves in a conflict between 'life-economy vs. life-health', providing 
resources to those in need, organizing the economy and the public health system (Fortes et al., 2020). Thus, economy and health represent, with due proportions, human lives. Consequently, they cannot be considered irreconcilable - a basic characteristic of a moral dilemma - within the same real ethical context.

The ethical debate carried out in this article, in the light of philosophy, can help to understand and even question statements offered by different areas of knowledge, such as public administration (Zappellini, 2013). Reflections and debates about phenomena of real life - such as the COVID-19 pandemic in 2020 - are needed. They highlight the ethical issues of public interest that government authorities are expected to deal with, making correct, quick, and conscious decisions to benefit the whole population, even in a context of scarcity of resources and information. When fully aware of the dilemmas involved in these decisions - among them the moral dilemmas - managers can count on a system of tools and reflections to better perform in such situations (Puiu, 2015). 


\section{REFERENCES}

Adler, M. (2020, March 31). Coronavírus: Moro descarta soltura de presos em massa e nega casos confirmados no sistema. Estado de Minas (Nacional). Retrieved from https://www.em.com.br/app/noticia/ nacional/2020/03/31/interna_nacional,1134355/ coronavirus-moro-descarta-soltura-de-presos-emmassa.shtml

Aung, K. T., Rahman, N., Nurumal, M. S., \& Ahayalimudin, N. (2017). Ethical Disaster or Natural Disaster? Importance of Ethical Issue in Disaster Management. Journal of Nursing and Health Science, 6(2), 90-93.

BBC. (2020, April 01). Coronavírus: por que a covid-19 afeta tanto os profissionais de saúde? (News - Brasil). Retrieved from https://www.bbc.com/ portuguese/internacional-52119508

Barone, I., \& Desideri, L. (2020, April 12). Estados usam dados de celulares para monitorar aglomerações. Eles podem fazer isso? Gazeta do Povo (Vida e Cidadania). Retrieved from https:// www.gazetadopovo.com.br/vida-e-cidadania/ monitoramento-celulares-aglomeracoes-covid-19/

Burke, J. (2001). Administrative Ethics and Democratic Theory. In T. L. Cooper (Ed.), Handbook of Administrative Ethics (2nd ed. rev. and exp., pp. 603-622), New York, NY: Marcel Dekker.

Carbone, B. L. (2020). O dilema médico: levando o inimigo para a própria casa. Sanarmed (Colunistas). Retrieved from https://www.sanarmed.com/odilema-medico-levando-o-inimigo-para-a-propriacasa-colunistas

Cellard, A. (2008). A análise documental. In J. Poupart. A pesquisa qualitativa: enfoques epistemológicos e metodológicos (pp. 295-316). Petrópolis, RJ: Vozes.

Conselho Nacional de Educação. (2020). Proposta de parecer sobre reorganização dos calendários escolares e realização de atividades pedagógicas não presenciais durante o período de pandemia da Covid-19. Retrieved from http://portal.mec. gov.br/index.php? option=com_docman\&vie $\mathrm{w}=$ download\&alias $=144511$ - texto-referenciareorganizacao-dos-calendarios-escolarespandemia-da-covid-19\&category_slug=marco2020-pdf\&Itemid=30192
Conselho Nacional de Justiça. (2020, March 17). Recomendação N. 62, de 17 de março de 2020. Recomenda aos Tribunais e magistrados a adoção de medidas preventivas à propagação da infecção pelo novo coronavírus - Covid-19 no âmbito dos sistemas de justiça penal e socioeducativo. Retrieved from https://www. cnj.jus.br/wp-content/uploads/2020/03/62Recomenda\%C3\%A7\%C3\%A3o.pdf

Cooper, T. L. (1998). The Responsible Administrator: an Approach to Ethics for the Administrative Role. 4th ed. São Francisco, CA: Jossey-Bass.

Cordeiro, W. M. (2017). Burocracia na construção da Administração Pública do século XXI: uma reflexão teórica. In Anais do $4^{\circ}$ Encontro Brasileiro de Administração Pública (pp. 801- 834), João Pessoa, PB, Brasil.

David, A. (2020, March 24). Coronavírus e a imediata soltura de presos: uma questão de direitos humanos. Brasil de Fato (Início - Opinião). Retrieved from https:/www.brasildefato.com.br/2020/03/24/artigocoronavirus-e-a-imediata-soltura-de-presos-umaquestao-de-direitos-humanos

Dondossola, E. (2020, April 22). 'Humilhante', diz grávida após passar a noite em fila de agência da Receita Federal no Rio. G1 (Bom Dia Rio). Retrieved from https://g1.globo.com/rj/rio-de-janeiro/ noticia/2020/04/22/humilhante-diz-gravida-apospassar-a-noite-em-fila-de-agencia-da-receitafederal-no-rio.ghtml

Drozenová, W. (2016). Challenge of time as a moral imperative. Human Affairs, 26(1), 80-89.

Dubnick, M. J., \& Justice, J. B. (2006). Accountability and the Evil of Administrative Ethics. Administration \& Society, 38(2), 236-267.

Figueiredo, N. M. A. (2007). Método e metodologia na pesquisa científica (2a ed.). São Caetano do Sul, São Paulo, SP: Yendis Editora.

Fortes et al. (2020). O direito à renda básica no Brasil em tempos de Covid-19. Retrieved from https://www. arca.fiocruz.br/handle/icict/40786

Freitag, B. (2005). Ética na administração pública. Revista do Serviço Público, 56(1), 85-94. 
French, P., \& Raymond, E. (2009). Pandemic Influenza planning: an extraordinary ethical dilemma for local government officials. Public Administration Review, 69(5), 823-830.

Gak, M. (2020). Opinion: Economy vs. human life is not a moral dilemma. Retrieved from https://www. dw.com/en/opinion-economy-vs-human-life-isnot-a-moral-dilemma/a-52942552

GaúchaZH. (2020, March 24). Ministério Público questiona medidas que atingem o direito de ir e vir do cidadão. Retrieved from https://gauchazh.clicrbs. com.br/coronavirus-servico/noticia/2020/03/ ministerio-publico-questiona-medidas-queatingem-o-direito-de-ir-e-vir-do-cidadaock865o2ht07bj01pqdreegmv0.html

Gazeta do Povo. (2020, March 29). Os bloqueios contra o coronavirus e o direito de ir e vir (Editorial Opinião). Retrieved from https://www.gazetadopovo. com.br/opiniao/editoriais/bloqueios-coronavirusdireito-de-ir-e-vir/

Geale, S. K. (2012). The ethics of disaster management. Disaster Prevention and Management, 21(4), 445462.

G1. (2020, April 21). Com aulas suspensas, Câmara de Florianópolis aprova projeto para atividades online na rede municipal. Retrieved from https://g1.globo.com/ sc/santa-catarina/noticia/2020/04/21/com-aulassuspensas-camara-de-florianopolis-aprova-projetopara-atividades-online-na-rede-municipal.ghtml

Kidder, R. M. (2007). Como tomar decisões difíceis: muitas vezes na vida você precisa escolher entre o certo e o certo. São Paulo, SP: Gente.

Lesme, A. (2020, April 18). Justiça determina alteração do cronograma do Enem 2020 e mudanças são anunciadas. Brasil Escola (Notícias). Retrieved from https://vestibular.brasilescola.uol.com.br/enem/ justica-determina-alteracao-do-cronograma-doenem-2020-e-mudancas-sao-anunciadas/347735. html

Lisboa, A. M. (2018). Economia política aristotélica: cuidando da casa, cuidando do comum. Logeion: Filosofia da informação, 4(1), 36-72.

Magenta, M. (2020, April 03). Coronavírus: governo brasileiro vai monitorar celulares para conter pandemia. Terra Networks Brasil S.A (Notícias). Retrieved from https://www.terra.com.br/noticias/ coronavirus/coronavirus-governo-brasileiro-vaimonitorar-celulares-para-conter-pandemia,62ec11 0da1579b3ae5eb3971b82966b6k0liy3ms.html

McEntire, D. A. (2015). Disaster Response and Recovery: Strategies and Tactics for Resilience. Hoboken, NJ: Wiley.

Mello, I. (2020, March 28). Coronavírus: Gilmar Mendes mantém recomendação do CNJ por soltura de presos. UOL (Notícias - Política). Retrieved from https://noticias.uol.com.br/politica/ ultimas-noticias/2020/03/28/coronavirus-gilmarmendes-mantem-recomendacao-do-cnj-porsoltura-de-presos.htm

Ministério da Saúde do Brasil. (2020). Painel Coronavírus. Retrieved from https://covid.saude. gov.br/

Peci, A. (2020). Os recursos foram liberados: é preciso liberar e mobilizar a burocracia. Retrieved from https://portal.fgv.br/artigos/recursos-foramliberados-e-preciso-liberar-e-mobilizar-burocracia

Puiu, S. (2015). Ethical Dilemmas in the Public Sector. Management \& Marketing Journal, 13(1), 57-62.

Receita Federal. Ministério da Economia. (2020, April 08). Nota de esclarecimento sobre regularização do CPF para recebimento de auxílio emergencial de $R \$$ 600,00 para trabalhadores informais, desempregados, MEIs e contribuintes individuais do INSS. Retrieved from https://receita.economia.gov.br/noticias/ ascom/2020/abril/nota-de-esclarecimento-sobreregularizacao-do-cpf-para-recebimento-de-auxilioemergencial-de-r-600-00-para-trabalhadoresinformais-desempregados-meis-e-contribuintesindividuais-do-inss

Rego, S., Palácios, M., Fortes, P. D., Schramm, F. R., Costa, A., Brito, L., ... Gomes, A. P. (2020a). Existe o dever de falar a verdade no contexto da Covid-19? Retrieved from http://www.ensp.fiocruz.br/portalensp/informe/site/materia/detalhe/48745

Rego, S., Fortes, P., Barboza, H. H., Borges, L., Brito, L., Costa, A., ... Tome, B. (2020b). Existe o direito de dizer não no contexto da Pandemia Covid-19? Retrieved from https://www.researchgate.net/ publication/340875304_Existe_o_direito_de_dizer_ nao_no_contexto_da_Pandemia_Covid-19

Rossi, M. (2020, March 25). "Eu não poderia recuar nessa hora": o dilema dos profissionais da saúde que estão no grupo de risco. El País (Brasil). Retrieved 
from https://brasil.elpais.com/brasil/2020-03-25/ eu-nao-poderia-recuar-nessa-hora-o-dilema-dosprofissionais-da-saude-que-estao-no-grupo-derisco.html

Saldaña, P. (2020, April 16). Com Enem mantido, MPF quer que MEC mostre ações para assegurar ensino na pandemia. Folha de São Paulo (Educação). Retrieved from https://www1.folha.uol.com.br/ educacao/2020/04/com-enem-mantido-mpf-quermec-mostre-acoes-para-assegurar-ensino-napandemia.shtml

Santos, L. S. (2019). A ética da gestão pública à luz da abordagem da racionalidade: os dilemas morais vivenciados na gestão de riscos e desastres em Santa Catarina. (Doctoral Dissertation). Universidade do Estado de Santa Catarina, Florianópolis, Brasil.

Santos, L. S., \& Serafim, M. C. (2020). Quando o Desastre Bate à Porta: Reflexões sobre a Ética da Gestão Pública de Riscos e de Desastres. Administração Pública e Gestão Social, 12(2), 1-16.

Treviño, L. K., \& Nelson, K. A. (2010). Managing Business Ethics: Straight Talk About How To Do It Right. New York: John Wiley.
Valadares, M. (2020, March 23). Coronavírus faz educação a distância esbarrar no desafio do acesso à internet e da inexperiência dos alunos. G1 (Educação). Retrieved from https://g1.globo. com/educacao/noticia/2020/03/23/coronavirusfaz-educacao-a-distancia-esbarrar-no-desafio-doacesso-a-internet-e-da-inexperiencia-dos-alunos. ghtml

Villoria, M. (2011). Ética en el sector público: una reflexión desde la ética aplicada. Encuentros Multidisciplinares, 13(39), 19-28.

Waldo, D. (2000). Public Administration and Ethics: a Prologue to a Preface. In Stillman, R. J. (Ed.). Public Administration: Concepts and Cases (7th ed., pp. 472482). Boston, USA: Houghton Mifflin.

Zack, N. (2009). Ethics for Disaster. Lanham, MD: Rowman \& Littlefield.

Zappellini, M. B. (2013). Ética e Administração Pública: uma Abordagem a partir de três Modelos Normativos. In Anais do $37^{\circ}$ Encontro da Associação Nacional de Programas de Pós-graduação em Administração, Rio de Janeiro, RJ, Brasil.

\section{Laís Silveira Santos}

https://orcid.org/0000-0002-4737-5470

Ph.D. in Administration from the University of the State of Santa Catarina (ESAG/UDESC); Administrator at the Federal University of Santa Catarina (UFSC); Researcher of the AdmEthics Research Group - Ethics, Virtues and Moral Dilemmas in Administration. E-mail: lais.ssantos@yahoo.com.br 